\title{
Phytoplankton biomass and production in the southern North Sea
}

\author{
Ian Joint, Alan Pomroy \\ Natural Environment Research Council, Plymouth Marine Laboratory, Prospect Place, The Hoe, Plymouth PL1 3DH, \\ United Kingdom
}

\begin{abstract}
Surface chlorophyll concentrations in the southern North Sea have been contoured for a 15 mo period, from 4 August 1988 to 3 October 1989. Seasonal changes in chlorophyll concentration show low phytoplankton biomass in the western and central regions and highlight the high phytoplankton biomass which develops in the spring and early summer in the Southern and German Bights. ${ }^{14} \mathrm{C}$ measurements made on each of the survey cruises have been used to estimate primary production for the whole of the southern North Sea. These data also highlight very high daily rates of primary production in phytoplankton blooms in the eastern North Sea. Regional estimates, based on the ICES subdivisions of the North Sea, are $79 \mathrm{~g} \mathrm{C} \mathrm{m}^{-2} \mathrm{yr}^{-1}$ for Region 3", $199 \mathrm{~g} \mathrm{C} \mathrm{m}^{-2} \mathrm{yr}^{-1}$ for Region $4,261 \mathrm{~g} \mathrm{C} \mathrm{m}^{-2}$ $\mathrm{yr}^{-1}$ for Region 5, and $119 \mathrm{~g} \mathrm{C} \mathrm{m}^{-2} \mathrm{yr}^{-1}$ for Region $7^{\prime \prime}$ In winter and early spring, the euphotic depth in the region off the Belgian and Dutch coast is as great as the water column depth and light will reach the bottom sediments; this may be a factor in the early development of Phaeocystis blooms in these regions.
\end{abstract}

\section{INTRODUCTION}

The North Sea is an important temperate shelf sea, bounded by the industrialised nations of northern Europe. In the last decade, there has been increasing concern that anthropogenic influences have begun to have a detrimental effect on the North Sea ecosystem; events such as algal blooms are considered by some to be evidence of a change in community structure and function which is a direct consequence of terrestrial inputs. However, the scientific data base for the North Sea is generally inadequate to distinguish unequivocally between natural variability in the ecosytem and changes which result from anthropogenic influences. These shortcomings were recognised in 1987 in the Ministerial Declaration of the 2nd International Conference on the Protection of the North Sea (the London Declaration), which agreed that a coordinated research programme was essential for the North Sea to establish any environmental consequences of anthropogenic influences with greater confidence.

The need for improved scientific understanding of the North Sea ecosystem had already been recognised by the UK Natural Environment Research Council which, in 1986, established a large interdisciplinary project to study the southern North Sea. The objective of the 'North Sea Community Research Project' was to increase knowledge of the North Sea ecosystem by a combination of a large field sampling programme and extensive use of modelling. An intensive sampling period of 15 mo has resulted in a unique description of the seasonal changes which occurred from August 1988 until October 1989 (Howarth et al. 1993). This paper is concerned with the data obtained during the project on phytoplankton distribution and production.

There have been relatively few previous studies of primary production in the North Sea (Riegman \& Colijn 1991), and there is considerable bias in most sampling towards the coastal zones; there are some off-shore studies (Gieskes \& Kraay 1980, Gieskes \& Kraay 1984, Tijssen \& Wetsteyn 1984, Riegman \& Colijn 1991, Zevenboom et al. 1991) but these are generally restricted in both spatial and temporal coverage. This paper describes the seasonal changes in phytoplankton abundance and production from August 1988 until October 1989 and forms the most comprehensive survey to date of the primary productivity of the southern North Sea. 


\section{METHODS}

The North Sea survey. Samples were collected by RRS 'Challenger', which was based in the North Sea for 15 mo from August 1988 until October 1989 with the aim that, every 29 d, there would be 2 cruises, one cruise lasting 12 or $13 \mathrm{~d}$ which would sample the same track on each occasion to measure seasonal cycles, and the second cruise to study smaller scale phenomena. The survey track was designed by the Proudman Oceanographic Laboratory to sample gradients near all the major estuaries as well as to sample mixed and stratified regions of the southern North Sea (Howarth et al. 1993). The sampling strategy adopted was to measure a large number of parameters with continuous sampling as the ship steamed around the grid at full speed; in addition, there were 120 stations on the survey track where the whole depth of the water column was sampled; the position of the stations used in this paper were tidally corrected. The continuously measured parameters were salinity, temperature, chlorophyll fluorescence, turbidity, dissolved oxygen and nutrient concentrations. At each station, detailed vertical profiles were obtained using a Neil Brown Conductivity/Temperature probe, Chelsea Instruments fluorometer, SeaTech transmissometer and PAR (photosynthetically available radiation) sensors, constructed at the Plymouth Marine Laboratory. Discrete water samples were taken from 3 depths in the water column, from near surface, mid-water and near bottom, with Go-Flo or Niskin bottles (with teflon-coated springs) and were analysed for chlorophyll and nutrient concentrations; samples were preserved with Lugol's iodine for subsequent microscopic analysis of phytoplankton species. The data from the project are banked at the British Oceanographic Database Centre and are available as CD-ROM (NERC 1992).

Estimation of chlorophyll concentration. The nature of the survey, with large numbers of samples taken every month, required pragmatism. Therefore, chlorophyll concentrations were measured by spectrophotometric analysis of extracted pigments and by in vivo fluorescence analysis, rather than by HPLC which was considered to be too time-consuming for routine analysis. A single water sample (1 to 2 l) from each depth was filtered through glass fibre filters (Whatman GF/F) and frozen quickly on board ship; the samples were returned frozen to the Plymouth Marine Laboratory, where they were extracted with $90 \%$ acetone, assayed in a scanning spectrophotometer and the concentration of chlorophyll and phaeopigments calculated using the SCOR-UNESCO algorithms (Strickland \& Parsons 1972). Samples were not taken in duplicate because there is only a small constant analytical error in our routine procedure. An ANOVA of 186 duplicate samples taken in the Irish Sea in 1987, with chlorophyll concentrations ranging from 0.25 to $11.3 \mathrm{mg} \mathrm{m}^{-3}$, had a standard deviation of 0.094 ; therefore, over this range of chlorophyll concentrations, the mean of the duplicate samples \pm 2 SD $( \pm 0.188)$ is the approximate $95 \%$ distribution. With this small constant error in the analysis, it was not necessary to take duplicate samples for chlorophyll analysis.

The extracted chlorophyll data were then used to calibrate the shipboard fluorometers by comparing the chlorophyll concentration with the voltage output from the continuous flow and CTD fluorometers at the time that the samples were taken. The data presented in this paper are the extracted chlorophyll values determined by spectrophotometry. However, vertical profiles of chlorophyll fluorescence for each station can be accessed from the Project CD-ROM (NERC 1992).

Stations positions for each sample were tidally corrected by the Proudman Oceanographic Laboratory to the position at the beginning of the cruise period ( $\mathrm{Dr}$ Roger Proctor, Proudman Oceanographic Laboratory, pers, comm.). Contour plots were produced using a UNIMAP program, part of the UNIRAS software.

Primary production measurements. Primary production was measured at 1 station each day on every survey cruise. A simple system was designed for simulated in situ incubations. The apparatus consisted of a series of 6 Perspex tubes, with different neutral density filters to give a range of light transmission; surface seawater was pumped through each tube to maintain samples at ambient temperature. The light transmission of the 6 Perspex tubes gave 97,75,36,21, 6 and $1 \%$ of ambient irradiance. On each day of the survey cruises, water samples were taken before dawn from 6 depths (using either Go-Flo or Niskin bottles, with teflon-coated springs). These depths varied depending on the turbidity of the water and attempts were made to ensure that the water samples were taken from depths which would have an equivalent light profile to that in the incubator. Water samples were transferred to sterile tissue culture bottles, and inoculated with $185 \mathrm{kBq}(5 \mu \mathrm{Ci}) \mathrm{NaH}^{14} \mathrm{CO}_{3}$, supplied by Amersham International plc. Three bottles from each depth were placed in the appropriate neutral density incubation tube and 1 bottle was incubated in a black tube in the dark; the samples were incubated from dawn to dusk as the ship continued sampling on the survey track. To prevent any effect of ship's lights at night, the samples in the neutral density tubes were transferred at dusk to a black tube, which was also supplied with surface seawater to control temperature. After $24 \mathrm{~h}$ incubation, each sample was filtered through a $0.2 \mu \mathrm{m}$ pore-size Nuclepore polycarbonate filter, which was then dried and stored in a desiccator and returned to the Plymouth Marine Laboratory at the end of the cruise. 


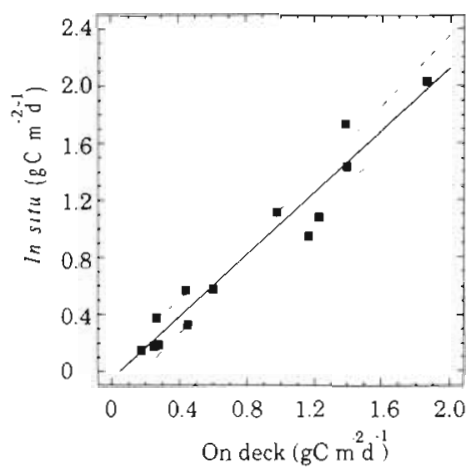

Fig. 1. Comparison of primary production measured on duplicate samples by 2 incubation methods: $24 \mathrm{~h}$ in situ incubations and on-deck incubations. (- - - ) approximate $95 \%$ confidence funnels

The ${ }^{14} \mathrm{C}$ content of the filters was determined in a liquid scintillation counter, the efficiency of which was determined with an external standard, channels ratio method.

The advantage of this simulated in situ incubation method was that the ship did not have to stop to do a conventional in situ incubation, an action which would not have been compatible with the survey mode of operation. However, it was necessary to calibrate the method to ensure that the results obtained were meaningful. This was done on 2 of the process cruises which took place between survey cruises in April and June 1989. Duplicate water samples were incubated both in a free-floating in situ incubation system, as described by Joint \& Pomroy (1983), and in the on-deck incubator. The results are compared in Fig. 1 ; in this analysis, $\mathrm{r}^{2}$ was $94.33 \%$. F-ratio was 183 with 12 degrees of freedom (df) and the slope of the line was 1.09. A similar intercalibration between in situ and simulated in situ incubations was done in the North Atlantic, using the same apparatus, and with a larger number (25) of experiments. This also showed no significant difference between the estimates obtained by the 2 methods (Joint et al. 1993) and we are confident that data obtained by the PML simulated in situ incubator are the same as would be obtained using conventional in situ incubations. In addition, Joint et al. (1993) reported the results of an intercalibration with Dutch scientists, using our in situ ${ }^{14} \mathrm{C}$ procedures, which give confidence to the primary production estimates.

Expanding the primary production data coverage. This procedure of pre-dawn sampling for primary production determinations resulted in 1 estimate $\mathrm{d}^{-1}$; on most cruises, a maximum of $10{ }^{14} \mathrm{C}$ incubations at different stations were done. In contrast, over 100 stations were sampled for chlorophyll concentration. Since phytoplankton production is dependent on chlorophyll concentration and light, as well as a number of factors such as temperature and nutrient concentration, attempts were made to find a way to expand the data coverage to that approaching the chlorophyll distribution. When the project was planned, we had anticipated the use of an algorithm linking specific primary production to surface insolation (Platt 1986). However, the irradiance sensor on the ship proved to be unreliable and there were insufficient data on surface irradiance. Various alternative relationships were explored but the best found was that between depth-integrated chlorophyll concentration and primary production. All the primary production measurements made during the North Sea surveys were used in this analysis and a good relationship was found between depth-integrated primary production and depth-integrated chlorophyll concentration. The total ${ }^{14} \mathrm{C}$ fixation from the sea surface to the depth at which ambient irradiance is $1 \%$ of the surface value was strongly correlated to the total amount of chlorophyll in the same depth of water (Fig. 2). The variance in chlorophyll concentration explains $69.75 \%$ of the variance in primary production $\left(r^{2}=69.75 \%\right.$, df $=122$, F-ratio $\left.=308.937, p<0.0001\right)$. The regression was not improved by adding such variables as temperature or beam attenuance, or by considering seasonality; the simple relationship between depth-integrated chlorophyll and depth-integrated primary production was accepted as the best way to utilise the large chlorophyll data set and to expand the primary production data coverage.

In order to obtain an estimate of primary production for each station where chlorophyll was measured, it was, therefore, necessary to know the depth of the euphotic zone. At each station, PAR sensors on the CTD system gave a measurement of light attenuation in the water column. These data were used to estimate the depth at which surface irradiance was reduced to $1 \%$ of the surface value. However, since the ship was sampling for $24 \mathrm{~h}$ each day, about half the stations where

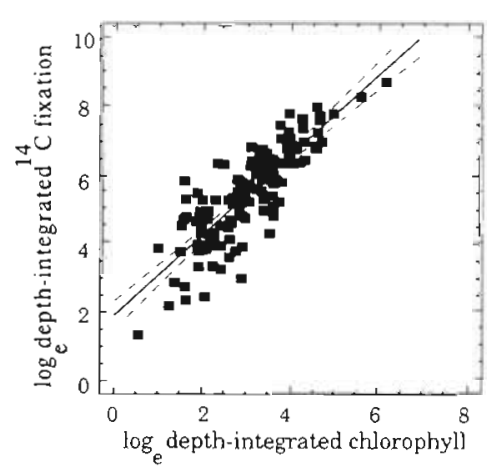

Fig. 2. Relationship between chlorophyll concentration in the water column, integrated from the surface to the depth at which irradiance is $1 . \%$ of the surface value, and the primary production in the same depth of water; all data are $\log _{e}$ transformed. (- - - ) approximate $95 \%$ confidence funnels 
chlorophyll was measured had no estimate of euphotic depth because the station was sampled at night. It was, therefore, necessary to estimate the $1 \%$ euphotic depth for these stations. Using data from stations sampled close to noon, a relationship was found between the euphotic depth and the transmissometer reading at $10 \mathrm{~m}_{\mathrm{i}}$ again, variance in transmissometer reading explained $68 \%$ of the variance in the euphotic depth $\left(\mathrm{r}^{2}=68.22 \%\right.$, df $=130, F$-ratio $\left.=276.91, \mathrm{p}<0.0001\right)$. Therefore, the transmissometer data could be used to estimate the euphotic depth for those stations which were sampled at night.

The overall procedure for obtaining an estimate of primary production at each station on the survey cruises is as follows. The depth of $1 \%$ surface irradiance was estimated from the transmissometer reading at $10 \mathrm{~m}$ depth for every CTD station on each cruise; the total chlorophyll concentration in the water column, from the surface to this depth, was calculated from the extracted chlorophyll data and these data were used to calculate the depth-integrated primary production for each station. These data were contoured to give distribution maps for primary production of the southern North Sea for each survey cruise.

Errors in this estimation procedure could be considerable. The small number of discrete chlorophyll samples at each station would not discriminate features such as chlorophyll maxima associated with the thermocline. However, we have examined each of the in vivo fluorometer vertical profiles and, of the 1446 stations used in this estimation of primary production, only 23 had inhomogeneity in chlorophyll concentration in the surface mixed layer to the depth of $1 \%$ light. A further 41 stations had accumulations of chlorophyll in seasonally stratified and near-coastal water, below the euphotic zone; this was presumably the result of settling of phytoplankton and these cells would not have contributed to the water column production.

We have attempted to estimate the overall errors involved in the adopted procedure by comparing 117 actual measurements of ${ }^{14} \mathrm{C}$ depth-integrated primary production with the values obtained from this estimation procedure, based on the chlorophyll present at each station. Fig. 3 shows a regression analysis of $\log _{e} Y=a+b \log _{e} X$, where $Y=$ estimated value $o b-$ tained from chlorophyll concentration by this method; $X=$ measured primary production by on-deck incubation); $a=0.728(\mathrm{SE}= \pm 0.231) ;$ and $b=0.871( \pm 0.042)$ $\left(\mathrm{r}^{2}=79.14 \%, \mathrm{df}=114, F\right.$-ratio $\left.=425, \mathrm{p}<0.0001\right)$. This means that this algorithm overestimates at low production and underestimates at high production. For example, at a high production rate of $2 \mathrm{~g} \mathrm{C} \mathrm{m}^{-2} \mathrm{~d}^{-1}$, the algorithm underestimates by $22 \%$ but at $0.2 \mathrm{~g} \mathrm{C} \mathrm{m}^{-2} \mathrm{~d}^{-1}$ there will be a $9 \%$ overestimation; at $0.3 \mathrm{~g} \mathrm{C} \mathrm{m}^{-2} \mathrm{~d}^{-1}$ the estimate has no bias. We have not attempted to

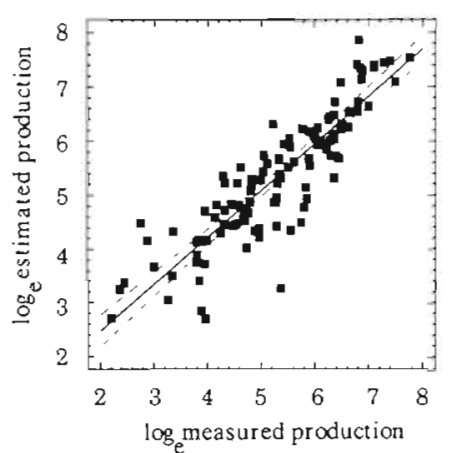

Fig. 3. Regression analysis of $\log _{e}$ primary production measured by on-deck incubation and $\log _{e}$ values of production estimated from the production-chlorophyll concentration algorithm. (- - -) approximate $95 \%$ confidence funnels

apply a correction factor to the primary production estimates, because there would also be errors involved in applying such a correction. Given the constraints of the method, we believe that the procedure we have adopted to expand the primary production data base does not introduce unacceptably high errors and the method has validity in estimating primary production over a large geographic and seasonal range of stations in the southern North Sea.

\section{RESULTS}

\section{Seasonal changes in chlorophyll distribution}

Sampling began on 4 August 1988 and continued until 3 October 1989. Although the sampling period covered 1 complete production season, it began towards the end of the first summer and, for convenience, the data will be considered in chronological order. The contour intervals in Fig. $4 \mathrm{a}$ to $\mathrm{d}$ are a geometric series which was chosen because it relates to the exponential growth rate of phytoplankton and each of the contours represents a doubling of the phytoplankton population. The distribution of the stations sampled is also shown on each of the contour charts.

In August 1988, chlorophyll concentrations were less than $2 \mathrm{mg} \mathrm{m}^{-3}$ (Fig. 4a) over most of the southern North Sea. There was a large region off the Dutch coast which had consistently higher chlorophyll concentrations throughout the 15 mo sampling period. The lowest concentrations were measured along the northern boundary of the survey area. In early September, (Fig. 4b) water with low $\left(<1 \mathrm{mg} \mathrm{m}^{-3}\right.$ ) chlorophyll concentrations extended through most of the western part of the region, with significantly higher chlorophyll concentrations in the German Bight and in Dutch coastal waters. Bad weather resulted in a reduced sampling 

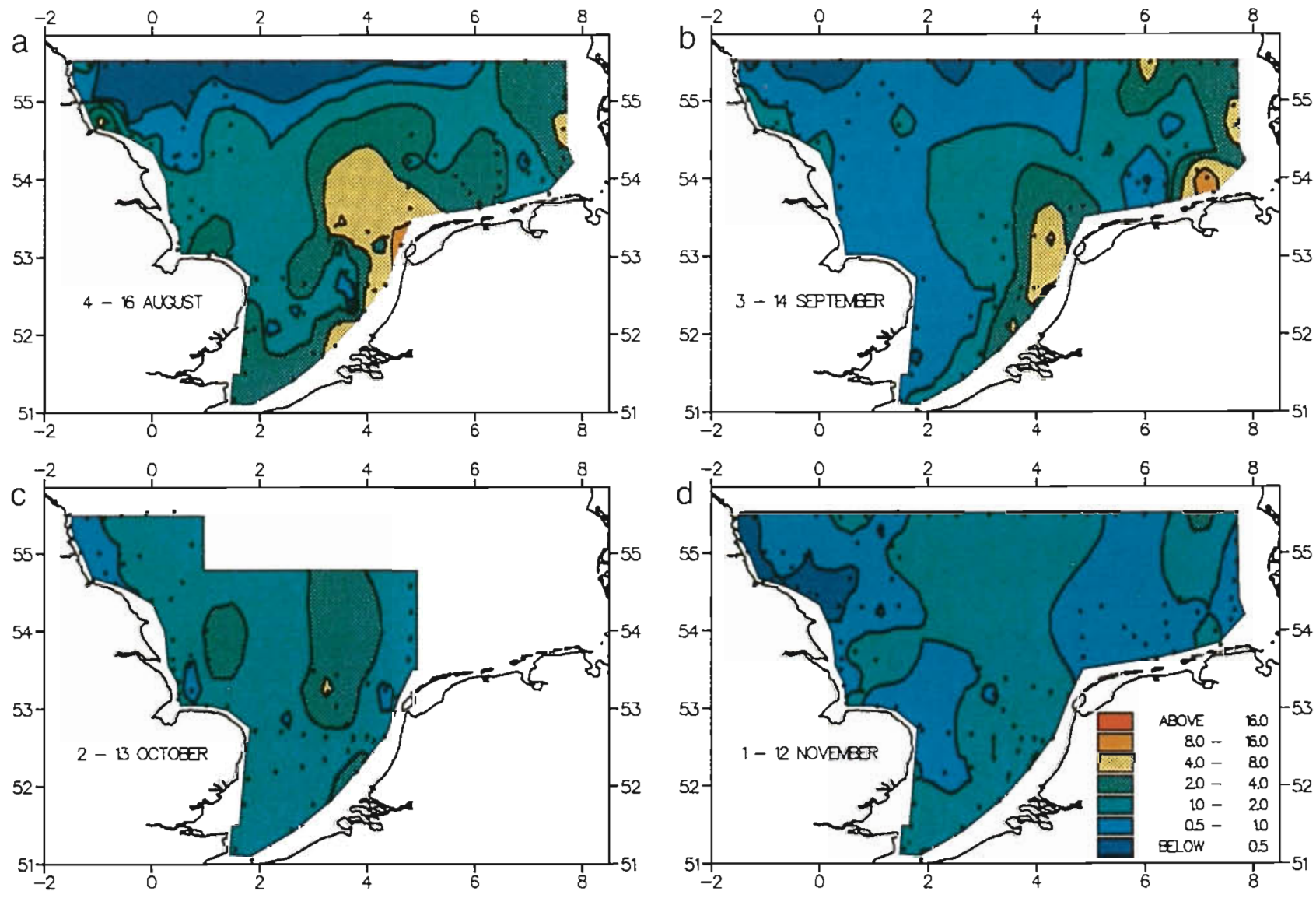

Fig. 4. Surface chlorophyll concentrations $\left(\mathrm{mg} \mathrm{m}^{-3}\right)$ for the survey cruises from August to November 1988. (a) 4 to 16 August 1988 . (b) 3 to 14 September 1988. (c) 2 to 13 October 1988. (d) 1 to 12 November 1988. (•) Stations used to produce the contour plot

grid in October 1988 (Fig. 4c) and there was no sampling in the eastern North Sea; however, in the region sampled, chlorophyll concentrations were slightly higher than in September. The seasonal decline in phytoplankton biomass in the coastal regions continued throughout November (Fig. 4d), although chlorophyll concentrations were still relatively high $(2$ to $4 \mathrm{mg} \mathrm{m}^{-3}$ ) in the southern and central North Sea.

Fig. $5 \mathrm{a}$ to $\mathrm{d}$ shows the situation throughout the winter of $1988 / 89$. Over a large proportion of the southern North Sea, chlorophyll concentrations were less than $0.5 \mathrm{mg} \mathrm{m}^{-3}$ and, between December and February, there were only a few isolated stations with chlorophyll concentrations greater than $2 \mathrm{mg} \mathrm{m}^{-3}$. The German Bight could not be sampled in December (Fig. 5a) and again, bad weather in early February (Fig. 5c) meant that it was impossible to sample some of the northern transect and no data are available for the central area. By the end of February, there was clear evidence that phytoplankton biomass was increasing again, particularly in the central regions; some of the highest con- centrations were measured at $56^{\circ} \mathrm{N}$, in the central region. Throughout the winter, very low chlorophyll concentrations were detected in the waters off the NE English coast, extending as far south as the Humber in January 1989.

By the end of March 1989, the biomass of phytoplankton was significantly increased; at some individual stations, chlorophyll concentrations were already greater than $8 \mathrm{mg} \mathrm{m}^{-3}$ (Fig. 6a). Again, this cruise took place during a period of poor weather and no samples were taken in the German Bight and along most of the $56^{\circ} \mathrm{N}$ transect. Of the stations sampled, the highest chlorophyll concentrations were in the Southern Bight, close to the Rhine. By the end of April (Fig. 6b), very high phytoplankton biomass was found in the coastal waters of Belgium, the Netherlands and into the German Bight; chlorophyll concentrations were $>8 \mathrm{mg}$ $\mathrm{m}^{-3}$ over most of the eastern North Sea, and at one station a value of $56 \mathrm{mg} \mathrm{m}^{-3}$ was measured. These very high chlorophyll concentrations were associated with extensive blooms of Phaeocystis sp., which were sam- 

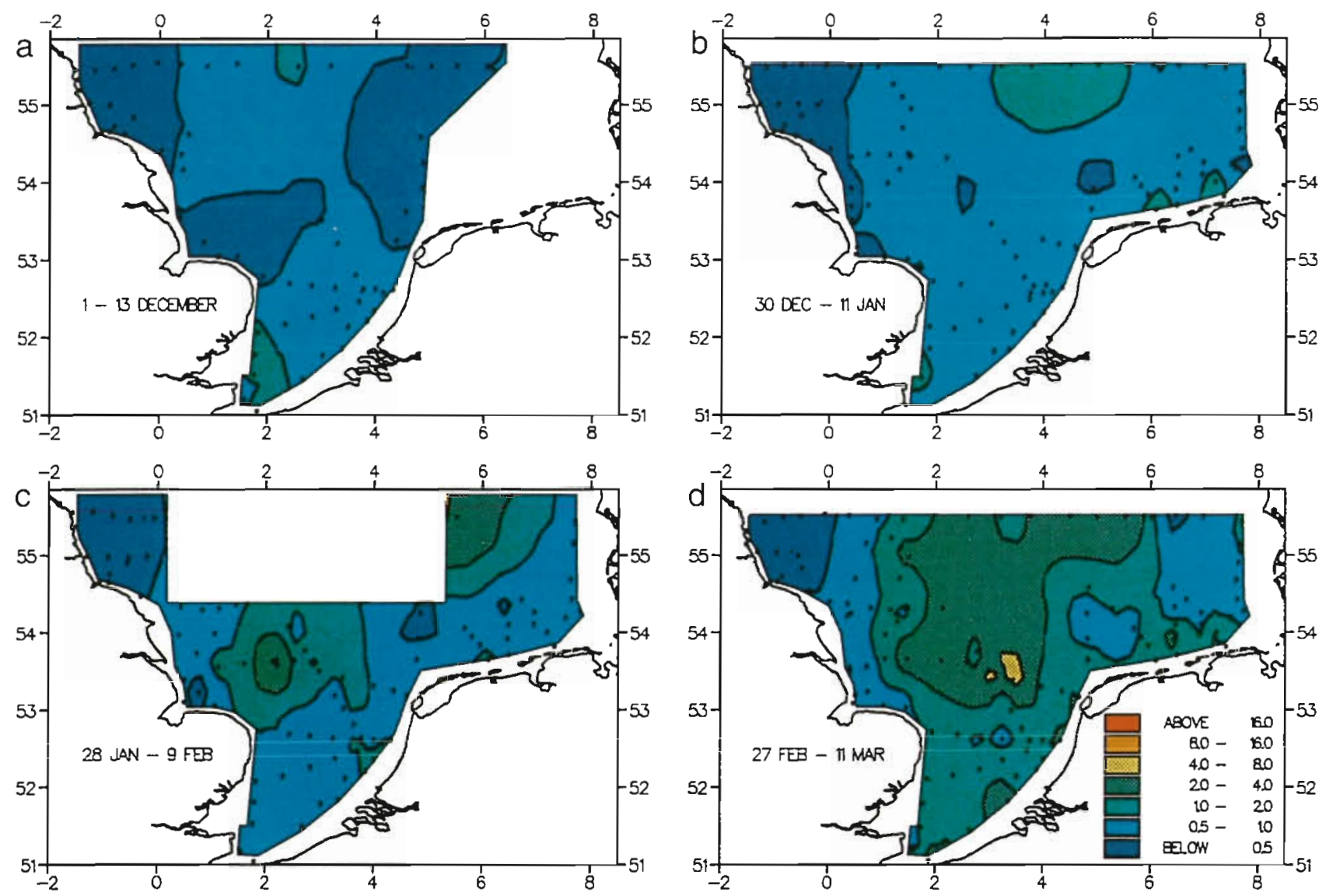

Fig. 5. Surface chlorophyll concentrations $\left(\mathrm{mg} \mathrm{m}^{-3}\right.$ ) for the survey cruises from December 1988 to March 1989 . (a) 1 to 13 December 1988. (b) 30 December 1988 to 11 January 1989. (c) 28 January to 9 February 1989. (d) 27 February to 11 March 1989. (•) Stations used to produce the contour plot
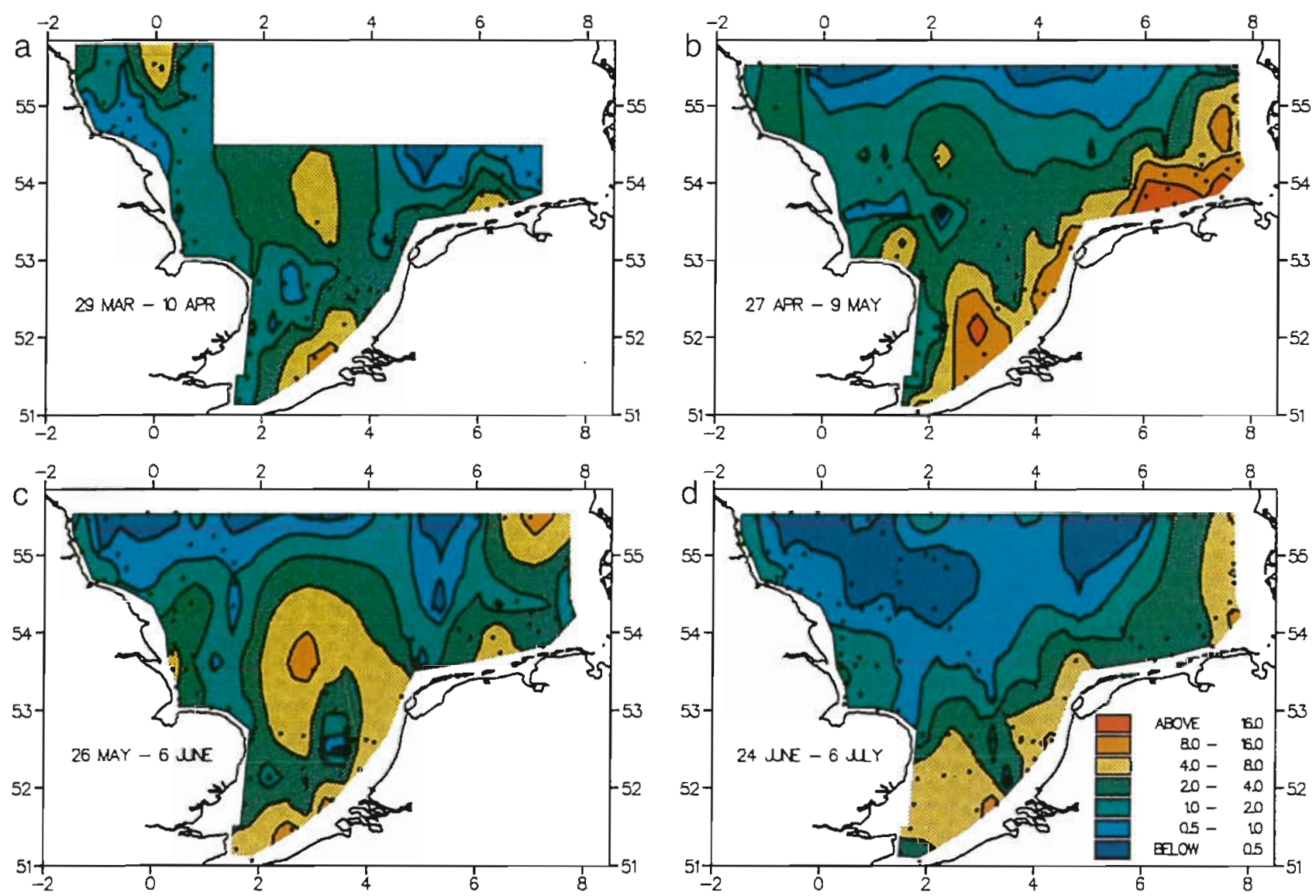

Fig. 6. Surface chlorophyll concentrations $\left(\mathrm{mg} \mathrm{m}^{-3}\right.$ ) for the survey cruises from March to July 1989. (a) 29 March to 10 April 1989. (b) 27 April to 9 May 1989. (c) 26 May to 6 June 1989. (d) 24 June to 6 July 1989. (•) Stations used to produce the contour plot 

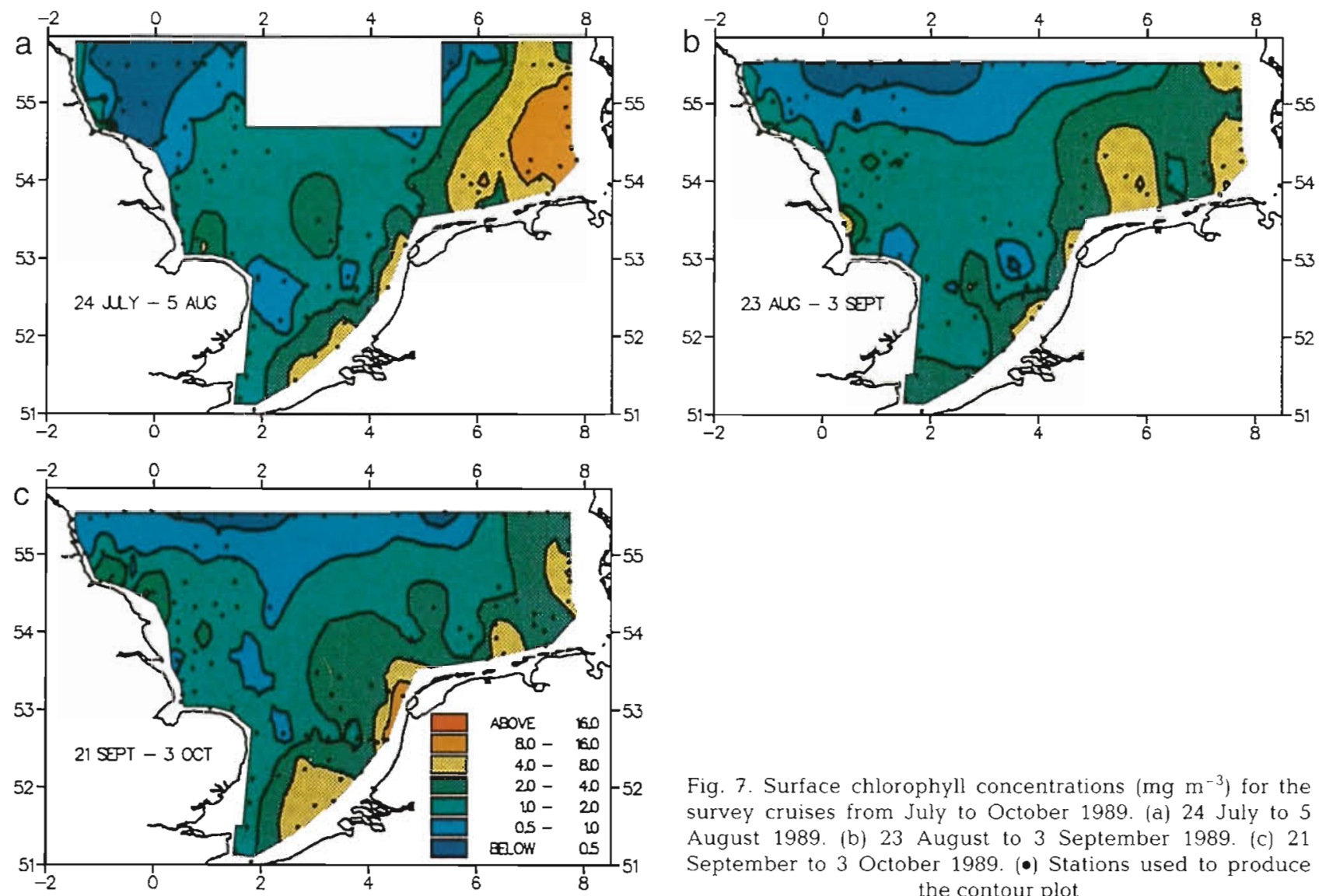

Fig. 7. Surface chlorophyll concentrations $\left(\mathrm{mg} \mathrm{m}^{-3}\right)$ for the survey cruises from July to October 1989. (a) 24 July to 5 August 1989. (b) 23 August to 3 September 1989. (c) 21 September to 3 October 1989. (•) Stations used to produce the contour plot

pled on each of the 2 survey and 1 process cruises between the end of March and middle of May. By the end of May (Fig. 6c), the extremely high chlorophyll concentrations were no longer present, although biomass did remain high (>4 $\mathrm{mg} \mathrm{m}^{-3}$ ) along the European coast. At this time there was evidence of the effect of the UK estuarine plumes, with higher chlorophyll concentrations being present close to the estuary of the river Humber and in the Wash. In late June/early July (Fig. 6d), chlorophyll concentrations declined over most of the central region and values of less than $0.5 \mathrm{mg} \mathrm{m}^{-3}$ were measured in the stratified waters in the north of the region sampled; higher phytoplankton biomass was still present in the mixed waters of the southern North Sea and in the German Bight.

The last 3 cruises during the North Sea Project in the late summer of 1989 showed a gradual return to the conditions which were first found in August 1988; Fig. $7 \mathrm{a}$ shows high biomass of phytoplankton in the German Bight in early August which decreased during August and September. Chlorophyll concentrations remained low through this period in the stratified waters to the north of the region. There was a striking similarity in the chlorophyll distributions in August 1988 and late August 1989; the reproducibility in the seasonality suggests that this represents a good description of the seasonal cycle of phytoplankton biomass in the southern North Sea.

\section{Phytoplankton production}

The distribution charts of primary production are largely similar to those of chlorophyll, as would be expected given the method by which we have estimated production. Fig. $8 \mathrm{a}$ to $\mathrm{d}$ shows the estimated phytoplankton production for the first 4 survey cruises, from August to November 1988. In the regions of high chlorophyll concentration, off the Dutch coast and in the German Bight, production was high, with more than $1 \mathrm{~g} \mathrm{C}$ fixed $\mathrm{m}^{-2} \mathrm{~d}^{-1}$ in August; production in these regions remained high in September, but over most of the southern North Sea, production was $<500 \mathrm{mg} \mathrm{C}$ $\mathrm{m}^{-2}$. Unfortunately, the limited sampling (Fig. 8c) in the German Bight due to bad weather during October 1988 means that we do not know how long primary production remained high during the autumn in this region. In November (Fig. $8 \mathrm{~d}$ ), carbon fixation rates were still ca $500 \mathrm{mg} \mathrm{C} \mathrm{m}^{-2} \mathrm{~d}^{-1}$ in the central region of 

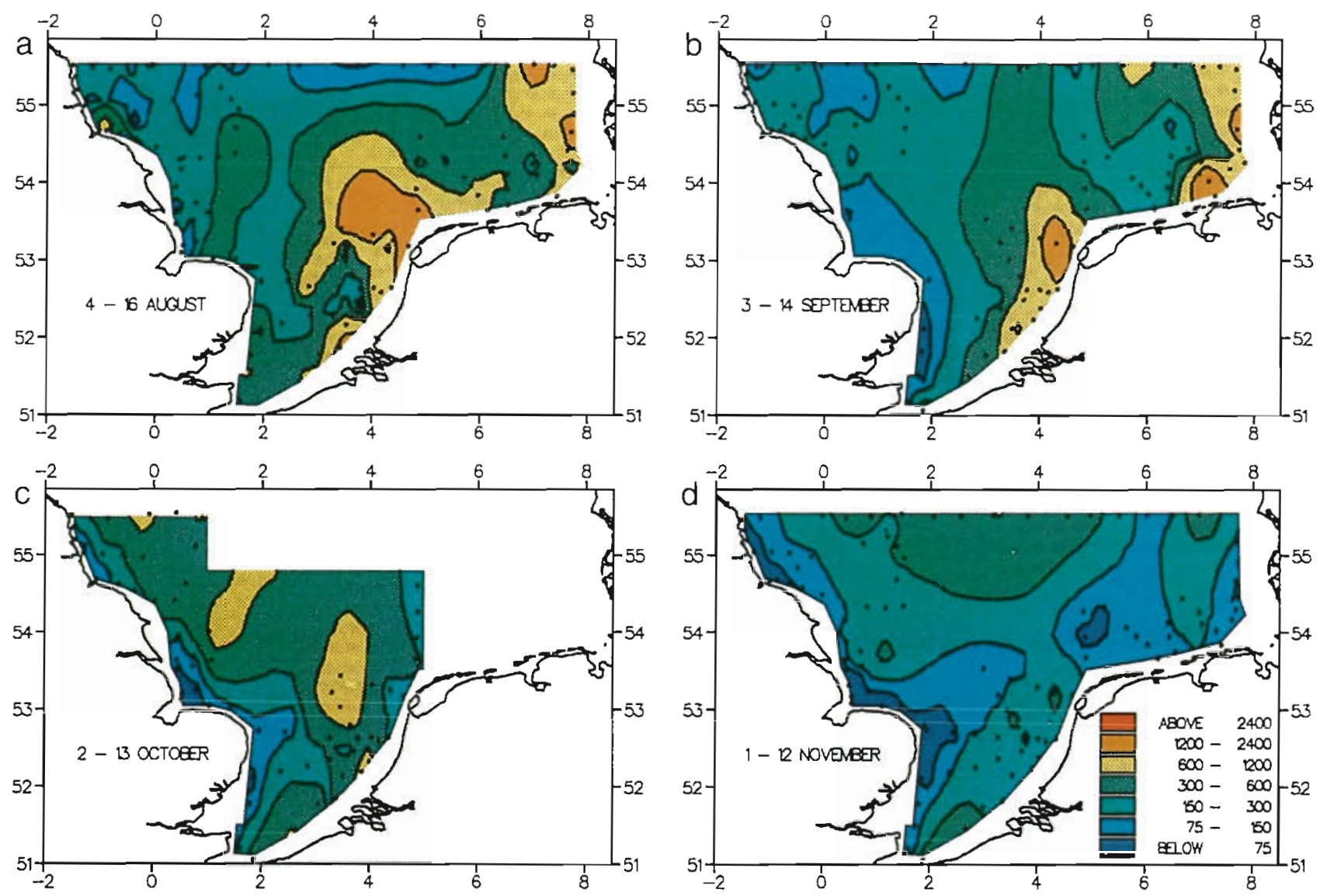

Fig. 8. As in Fig. 4 but for primary production ( $\mathrm{mg} \mathrm{C} \mathrm{m}^{-2} \mathrm{~d}^{-1}$ )
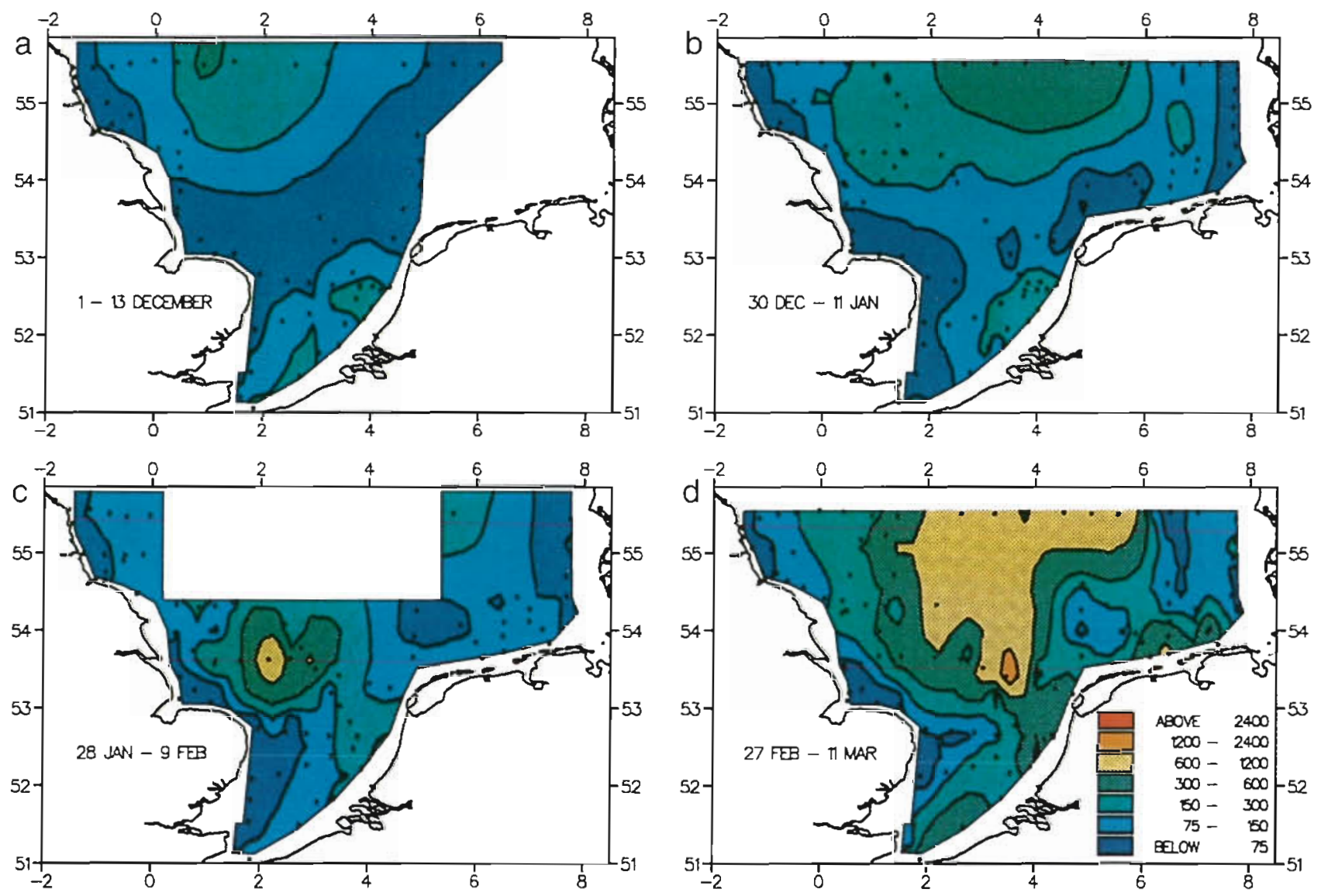

Fig. 9. As in Fig. 5 but for primary production $\left(\mathrm{mg} \mathrm{C} \mathrm{m}^{-2} \mathrm{~d}^{-1}\right)$ 

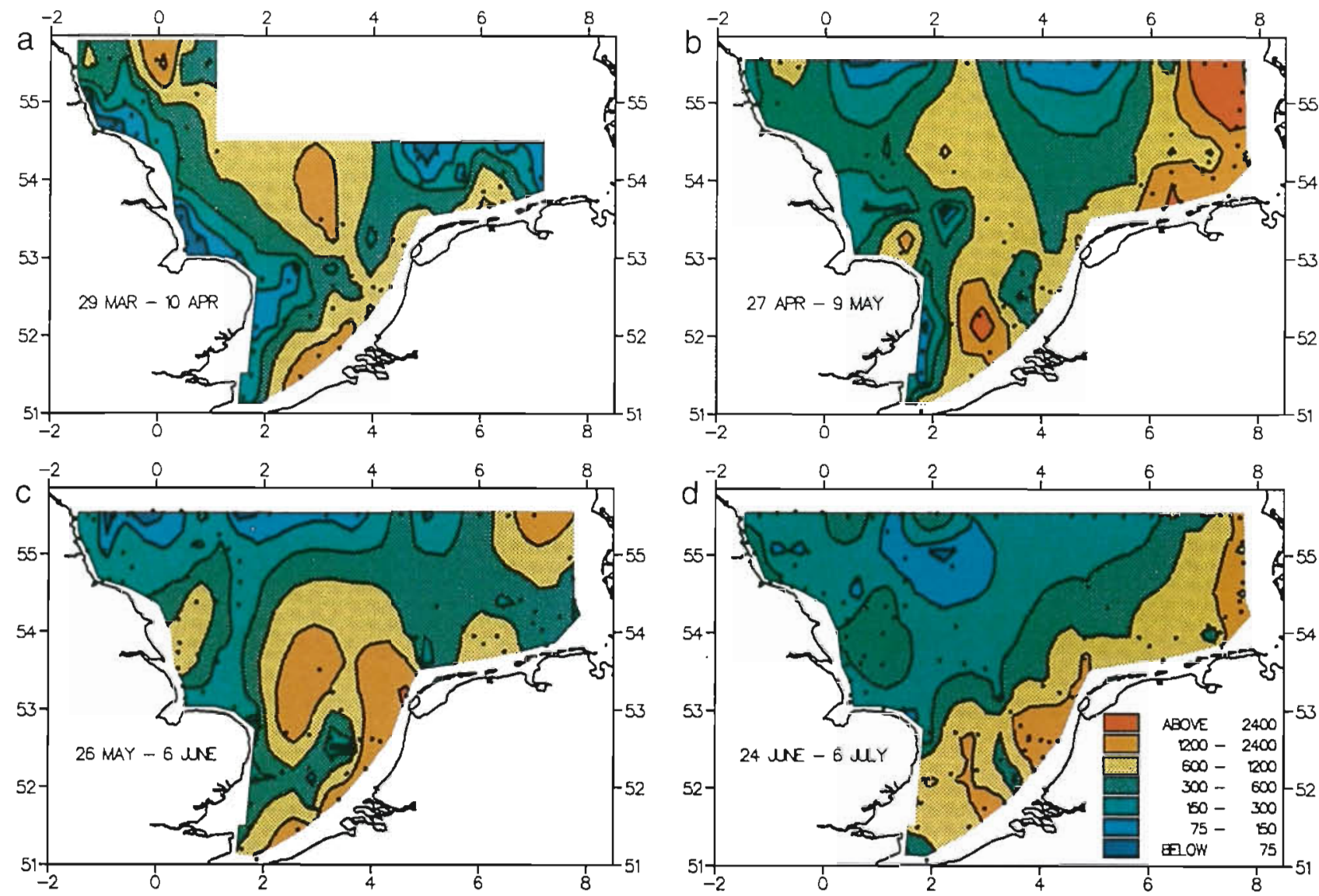

Fig. 10. As in Fig. 6 but for primary production $\left(\mathrm{mg} \mathrm{C} \mathrm{m}^{-2} \mathrm{~d}^{-1}\right)$

$56^{\circ} \mathrm{N}$ but rates had declined over the rest of the region and were particularly low along the English coast.

The primary production rates during the winter are shown in Fig 9a to d, and correspond to the chlorophyll distributions shown in Fig. 5. Phytoplankton activity was very low in the Southern Bight and the highest rates in the winter occurred in the central, northern region during December and January, when a number of stations had carbon fixation rates $>300 \mathrm{mg} \mathrm{C} \mathrm{m}^{-2}$ $\mathrm{d}^{-1}$. This region was not sampled in early February, although one station at $56^{\circ} \mathrm{N}, 5^{\circ} 30^{\prime} \mathrm{E}$ did appear to show higher production than adjacent waters in the German Bight, but by early March, carbon fixation rates were over $1 \mathrm{~g} \mathrm{C} \mathrm{m}^{-2} \mathrm{~d}^{-1}$ at some stations in the central region. Therefore, phytoplankton growth first increases in the north central region of the southern North Sea, rather than in the southern areas in which Phaeocystis blooms occur. Throughout the winter, the UK coastal region, as well as the German Bight, had very low rates of primary production which were generally less than $75 \mathrm{mg} \mathrm{C} \mathrm{m}^{-2} \mathrm{~d}^{-1}$

In early April, primary production increased along the continental coast during bloom development (Fig. 10a); the highest daily rates of primary production occurred in the German Bight in early May when carbon fixation rates were greater than $2.4 \mathrm{~g} \mathrm{C} \mathrm{m}^{-2} \mathrm{~d}^{-1}$. High rates were measured in this coastal zone until the end of the survey in late September (Fig. 11a to c). Production in the German Bight declined in late May as a result of the decrease in chlorophyll concentration. The lowest rates of primary production were along the English coast, although there were frequent increases in chlorophyll concentration and primary production in the vicinity of the Humber, particularly in May-June, June-July, August-September and SeptemberOctober. As with the chlorophyll distribution maps, there were strong similarities in the contour charts in August 1988 and late August 1989, suggesting a reproducible seasonal pattern in phytoplankton production.

\section{Primary production in the ICES subdivisions of the North Sea}

There are clear regional differences in the phytoplankton biomass and production in the southern 

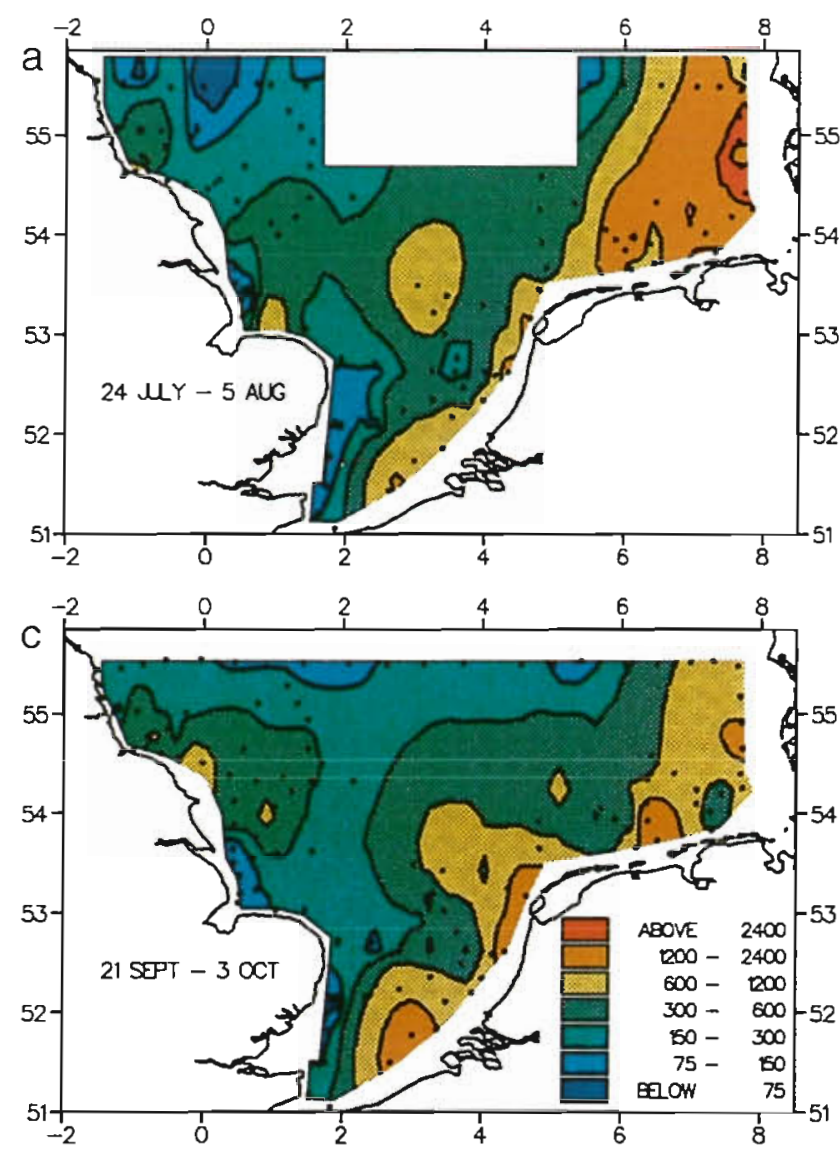

North Sea. Since phytoplankton activity is influenced by hydrographic conditions, it is logical to consider phytoplankton in relation to the physical conditions pertaining to the different areas. We have used the subdivisions proposed by the ICES Study Group on the flushing times of the North Sea (ICES 1983). There are 4 complete ICES subdivisions within the area covered by the survey cruises; these are Boxes 3", 4, 5 and 7 ". Small parts of Boxes $3^{\prime}$ and $7^{\prime}$ were also sampled along the northern transect but the number of stations within these areas was small and could not be taken to be representative of these regions which were to the north of the area sampled. Fig. 12 shows the ICES boxes and the primary production estimated for each month from August 1988 to September 1989. Primary production estimates for each station which occurred within an ICES box were used to obtain an average value for the region for the period of the cruise; an estimate of production for the period between the cruises was obtained by linear interpolation. The estimates were obtained for each calendar month by assuming a constant production rate for each of the cruise and intercruise periods and applying those rates to the appropriate number of days in each month.

ICES Box 3" covers the coastal region from the Tees

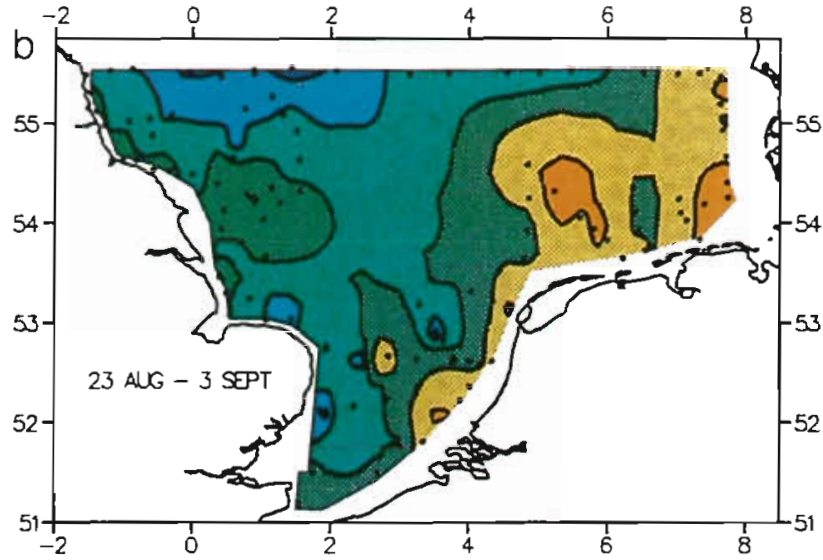

Fig. 11. As in Fig. 7 but for primary production $\left(\mathrm{mg} \mathrm{C} \mathrm{m}^{-2} \mathrm{~d}^{-1}\right)$

to the Thames; the region is characterised by a slowmoving southerly drift and decreasing salinity to the south (ICES 1983). The water column is generally well mixed, with little evidence of thermal stratification at any season. Chlorophyll concentrations were generally low in the surface waters. At a few stations, elevated values of ca $3 \mathrm{mg} \mathrm{m}^{-3}$ were recorded below $25 \mathrm{~m}$ in

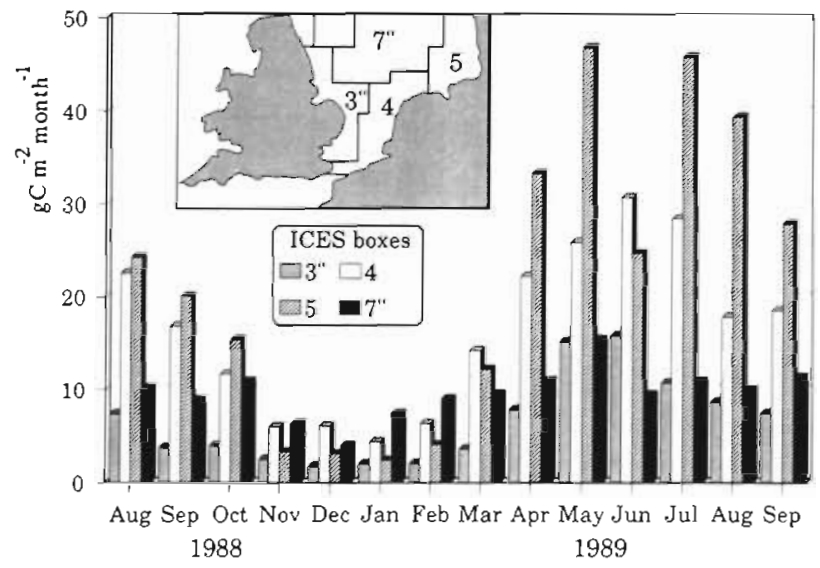

Fig. 12. Estimated monthly primary production $\left(\mathrm{g} \mathrm{C} \mathrm{m}^{-2}\right.$ $\mathrm{mo}^{-1}$ ) for the 4 ICES subdivisions in the survey area (shown in the inset) 
May; the most likely explanation is that there was sinking of phytoplankton from the surface. This region had the lowest rates of primary production (Fig. 12) of the 4 regions in every month except June, when the production in Region 7" was lower; production was particularly low during the winter. The data in Fig. 12 have been used to calculate the annual primary production for the period 1 August 1988 to 31 July 1989 and this is estimated to be $79 \mathrm{~g} \mathrm{C} \mathrm{m}^{-2} \mathrm{yr}^{-1}$ for ICES Box 3".

ICES box 4 is the region where intense blooms of Phaeocystis develop, with greatest biomass occurring in the coastal regions (Fig. 6). ICES Box 4 is characterised by an inflow of Channel water which is mixed with coastal water (ICES 1983). There was little evidence of thermal stratification and chlorophyll concentrations were usually well mixed through the water column. This region had higher rates of primary production through the winter than Box 3" (Fig. 12) and very high rates in the spring which were sustained throughout the summer. Phytoplankton activity remained high through September and October. Blooms of Phaeocystis were found in April and May but a mixed phytoplankton assemblage was present in the summer; flagellates, dinoflagellates and diatoms were present, with an increasing importance of dinoflagellates in the late summer (NERC 1992). This region was most productive in June 1989, when the carbon fixation rate was $30 \mathrm{~g} \mathrm{C} \mathrm{m}^{-2} \mathrm{mo}^{-1}$. The annual production for Region 4 is estimated to be $199 \mathrm{~g} \mathrm{C} \mathrm{m}^{-2} \mathrm{yr}^{-1}$

ICES Box 5 is largely a coastal water mass with regions of both thermal and haline stratification (ICES 1983); the high chlorophyll concentrations measured in April and May occurred at times of haline stratification. Winter primary production was lower in this region than in Region 4 but this was also where the highest rates of carbon fixation were measured. There was a large increase in production in April and May 1989 , which then declined in June before reaching high values again in July and August. As in Region 4, phytoplankton production remained high through September and October but had declined significantly by November. The annual primary production of Region 5 is estimated to be $261 \mathrm{~g} \mathrm{C} \mathrm{m}^{-2} \mathrm{yr}^{-1}$.

The central region of the survey area covered ICES Box 7", although most of the data were collected on the transect which ran along the northern boundary, which crosses the Dogger Bank. The region is characterised by a strong seasonal thermocline and a Central North Sea water mass (ICES 1983). The strong seasonal stratification results in nutrient depletion in the surface mixed layer in summer (NERC 1992). The seasonal variation in primary production (Fig. 12) shows the least range in values for any of the 4 regions, with the highest winter carbon fixation rates and, generally,

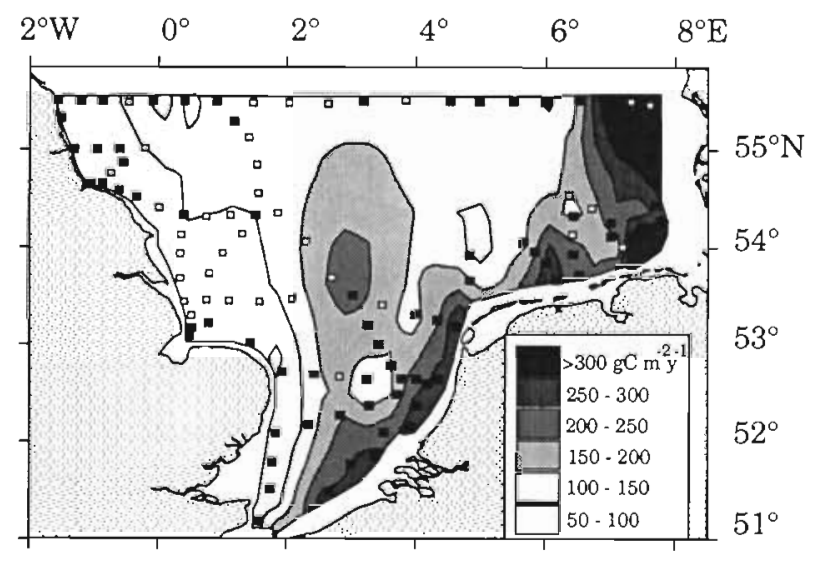

Fig. 13. Contour plot of annual primary production $\left(\mathrm{g} \mathrm{C} \mathrm{m}^{-2}\right.$ $\mathrm{yr}^{-1}$ ) for the southern North Sea based on each individual station. Estımates between cruise periods were obtained by linear interpolation. (a) Stations used to produce the contour plot; if a station was not visited on 2 consecutive cruises during the survey period, the data were not included in this contour but the stations are indicated by $\square$

the lowest summer rates. The production rates in this central region in January and February were double those in the German Bight and almost 3 times those in the UK coastal waters. The highest production rates were measured in May (15.4 $\mathrm{g} \mathrm{C} \mathrm{m}^{-2} \mathrm{mo}^{-1}$ ) and this decreased slightly to $\mathrm{ca} 10 \mathrm{~g} \mathrm{C} \mathrm{m}^{-2} \mathrm{mo}^{-1}$ through the summer. In both years, there was a slight increase in production in the autumn (October 1988 and September 1989) but there was no strong evidence of an autumn phytoplankton bloom in this region. The annual primary production for ICES Region $7^{\prime \prime}$ is estımated to be $119 \mathrm{~g} \mathrm{C} \mathrm{m}^{-2} \mathrm{yr}^{-1}$

Fig. 13 shows a contour plot of annual primary production for the southern North Sea based on each ind1vidual station. It is clear that the least productive region of the southern North Sea is along the UK coast; the boundaries of the $100 \mathrm{~g} \mathrm{C} \mathrm{m}^{-2} \mathrm{yr}^{-1}$ contour are similar to ICES Region 3 ". Similarly, the most productive regions, in the Southern and German Bights, appear to be well characterised by the ICES boxes, albeit with an offshore gradient. The central region, ICES Box 7", was the least well-sampled of the regions but, again, Fig. 13 suggests that the ICES boxes are appropriate for subdividing the primary production of the southern North Sea.

\section{DISCUSSION}

The data presented in this paper are one of the most comprehensive temporal and spatial surveys of a coastal sea; it is rare for an area as large as the southern North Sea to be sampled at all, let alone at a 
monthly frequency for over 15 mo. However, in spite of the comprehensiveness of the data, there remain uncertainties over whether this period was typical; Howarth et al. (1993) report that the observational period was drier than the average for 1961 to 1990 , with river discharges averaging $25 \%$ less for the period of the project. Air temperatures were also higher and 1989 was about $1^{\circ} \mathrm{C}$ warmer than average. It is not known how these conditions might have influenced North Sea plankton. Nevertheless, despite these uncertainties, the data in this paper represent the best estimate to date of phytoplankton biomass and primary production.

Previous estimates of primary production in the North Sea have relied on less comprehensive data. For example, Gieskes \& Kraay (1984) obtained data in May, July and September and extrapolated from these values to estimate the annual production of the central North Sea to be $250 \mathrm{~g} \mathrm{C} \mathrm{m}^{-2} \mathrm{yr}^{-1}$. This appears to be high since, in 1988-1989, we estimate the primary production of the central region of the southern North Sea to be $119 \mathrm{~g} \mathrm{C} \mathrm{m}^{-2} \mathrm{yr}^{-1}$. A different approach was taken by Horwood (1982), who used a model to infer that annual production off the north-east coast of England was low, at about $40 \mathrm{~g} \mathrm{C} \mathrm{m}^{-2} \mathrm{yr}^{-1}$; the data presented in the current paper confirms that this is indeed an area of lower phytoplankton production but, at $79 \mathrm{~g} \mathrm{C}$ $\mathrm{m}^{-2} \mathrm{yr}^{-1}$ the production is not quite as low as Horwood estimated. Riegman \& Colijn (1991) measured the average daily primary production of the Dogger Bank area to be $1.2 \mathrm{~g} \mathrm{C} \mathrm{m}^{-2} \mathrm{~d}^{-1}$ in July and August. These values are slightly higher than reported here, but they were made over a period of only $15 \mathrm{~d}$ in 1988; primary production rates measured in this paper are, however, close to the range of values quoted by Riegman \& Colijn (1991), Lancelot \& Mathot (1987) estimated primary production in the Belgian coastal waters during a Phaeocystis-dominated bloom in the spring to be $84 \mathrm{~g}$ $\mathrm{C} \mathrm{m}^{-2} \mathrm{mo}^{-1}$; our estimate for the same time of year is $\mathrm{ca}$ $30 \mathrm{~g} \mathrm{C} \mathrm{m}^{-2} \mathrm{mo}^{-1}$ for ICES Box 4 . Box 4 includes a large area offshore, where Phaeocystis was less important and which was not sampled by Lancelot \& Mathot, and may explain our lower estimates; some stations sampled during the North Sea Survey did have chlorophyll concentrations and phytoplankton production which were comparable to those reported by Lancelot \& Mathot and, given the year to year variability of the North Sea ecosystem, our data are not inconsistent with those of Lancelot \& Mathot (1987).

There have been few attempts to estimate primary production for large regions in the North Sea. Satellite remote-sensing has given some useful indications of the regional variations in chlorophyll concentration (Holligan et al. 1989) but uncertainties in calibration algorithms and the frequency of cloud cover have meant that existing estimates of primary production for the North Sea have relied on data sets with limited geographical coverage. On the basis of literature data Reid et al. (1990) estimated that primary production was 150 to $200 \mathrm{~g} \mathrm{C} \mathrm{m}^{-2} \mathrm{yr}^{-1}$ in the northern North Sea, $250 \mathrm{~g} \mathrm{C} \mathrm{m}^{-2} \mathrm{yr}^{-1}$ in the central North Sea and $200 \mathrm{~g} \mathrm{C}$ $\mathrm{m}^{-2} \mathrm{yr}^{-1}$ in the south. We have no data for the northern North Sea and the regions in the south are not strictly comparable, but the data presented in this paper suggest that Reid et al. may have slightly underestimated phytoplankton activity in the southern North Sea but overestimated production in the central region; if ICES Region 7 "is representative of the central North Sea, then the annual production is about half that estimated by Reid et al. In those regions in the Southern and German Bights where phytoplankton blooms occur, the annual primary production is $\mathrm{ca} 200$ to $250 \mathrm{~g} \mathrm{C}$ $\mathrm{m}^{-2} \mathrm{yr}^{-1}$.

There has been much discussion about the factors which result in phytoplankton blooms, particularly those of the colonial form of Phaeocystis pouchetti which occur every year in the spring in the southern North Sea; this single species has been estimated to comprise up to $96 \%$ of the total phytoplankton biomass at times (Zevenboom et al. 1991). Attention has focussed on the role of nutrients and possible enrichment from agrochemicals. Although increased nutrient supply can result in a greater biomass and production of phytoplankton, it does not necessarily explain why certain species form blooms. At the time of the initial development of colonial Phaeocystis in 1989, nitrate concentrations were only slightly less than winter values (NERC 1992) and it was as a consequence of the growth of $P$. pouchetti that the nutrient concentrations declined. It has been suggested (Veldhuis et al. 1986 , Lancelot \& Mathot 1987) that Phaeocystis blooms follow a diatom bloom, which exhausts silicate but does not remove all nitrate and phosphate and these nutrients are then available to Phaeocystis. However, this succession does not always occur and Davies et al. (1992) have described a Phaeocystis bloom which occurred in coastal waters without a major diatom bloom: similarly, in the North Sea in 1989, there was no evidence of a diatom bloom in the eastern North Sea at the time that samples were taken and the Phaeocystis bloom was not preceded by silicate depletion.

Clearly, the factors involved in Phaeocystis bloom initiation are a complex interaction between growth, grazing and nitrate and phosphate ratios (Verity et al. 1988) but perhaps insufficient attention has been paid to irradiance rather than to nutrient concentration. Davies et al. (1992) have suggested that the initiation of a Phaeocystis bloom may occur when growth begins of cells which have persisted throughout the winter on the sediment. In these circumstances, light would be 

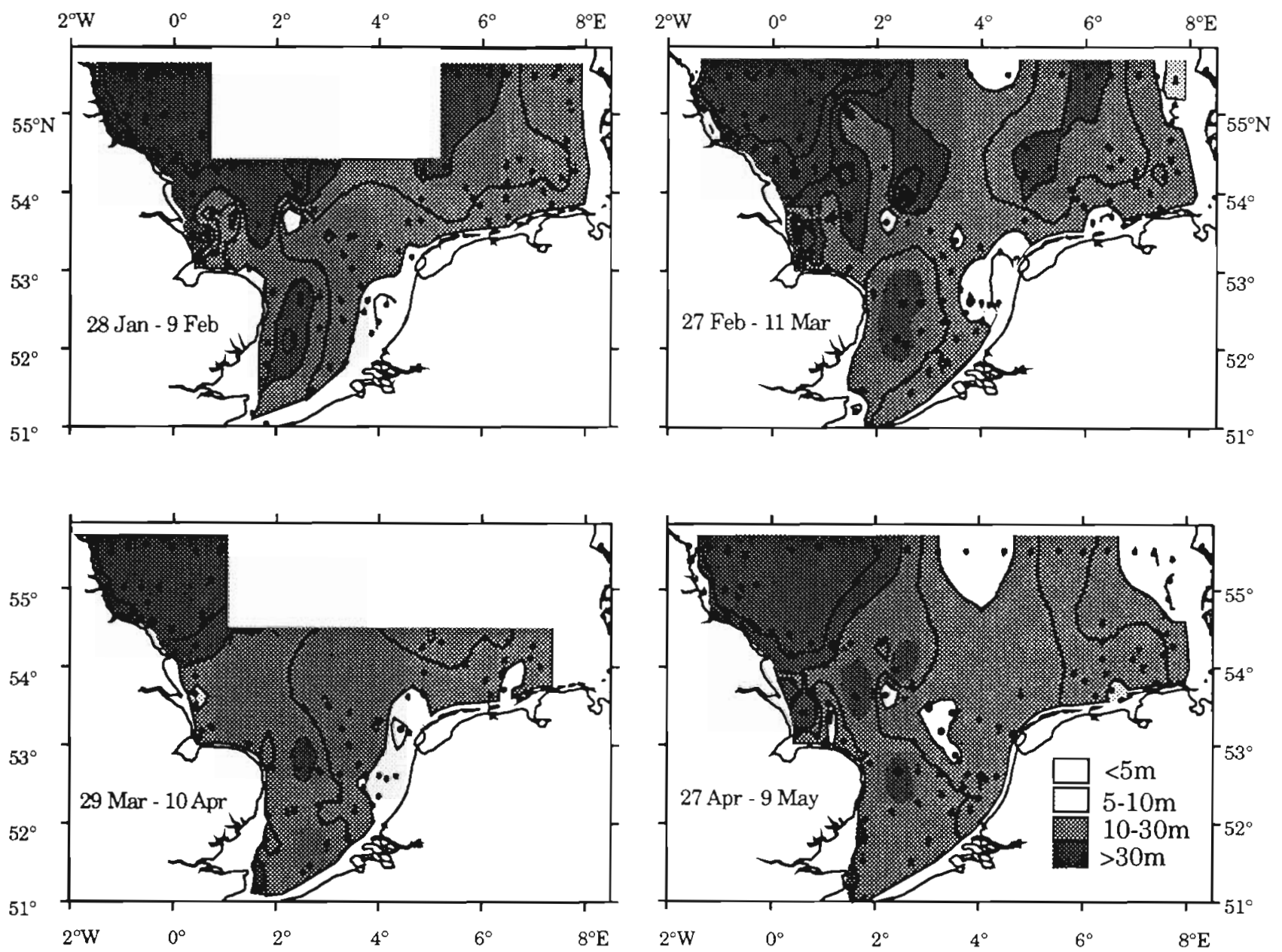

Fig. 14. Contour chart of the estimated distance of the base of the euphotic zone (1\% irradiance) from the sea bed for 4 periods from January to May 1989. The depth of the water column was taken from the ship's echo sounder; the depth of $1 \%$ irradiance was estimated with a submersible $4 \pi$ sensor at those stations sampled close to mid-day. $(\bullet)$ Stations used to produce the contour plot

required to penetrate to the sea bed in the late winter for growth of Phaeocystis to be initiated. Fig. 14 shows contour charts of the proximity of the depth of $1 \%$ irradiance to the sea bed. From December 1988 through to March 1989, the $1 \%$ light level was at or very close to the sea bed in parts of the coastal regions of Belgium and the Netherlands, and it was only with the development of high phytoplankton biomass in April that the euphotic depth decreased. These regions of high light penetration occurred where Phaeocystis blooms and this could be part of the explanation for recurrent blooms in this region of the southern North Sea. At some stations the euphotic depth was greater than the water column depth and there was clearly the potential for growth of photosynthetic arganisms on the sediment surface. If Davies et al. (1992) are correct in suggesting that there may be overwintering of Phaeocystis on the sea bed, then there would appear to be sufficient light penetrating throughout the water column for photosynthesis to take place. Since Phaeocystis is a shade phytoplankton (Lancelot \& Mathot 1987), which has efficient photosynthesis at low irradiance, the high light penetration in the water column in these regions of the southern North Sea could be a major factor in the initiation and development of blooms.

These localised turbidity minima in those regions off the Belgian and Dutch coasts in winter are a recurrent feature of the region and appear to be a consequence of relatively large Rhine discharges and the steep salinity gradients which develop in winter and early spring (Visser et al. 1991). Therefore, the conditions of light penetration through the water column in these regions appear to be particularly favourable for the early growth of phytoplankton which are present, not only in the water column, but also on the sediment surface. More research is required to prove the hypothesis of Davies et al. (1992) but it is a plausible explanation for the initiation of nuisance blooms of Phaeocystis. 
Acknowledgements. This research would not have been possible without the enthusiastic participation of many people. Jane Evans analysed a very large number of chlorophyll samples. The work at sea on the Survey cruises was done very effectively by Bob Head, Mike Jordan, Ken Jones, Dave Mills, Duncan Plummer and Jocelyn Richard, as well as by the authors. We owe a particular debt to Roy Lowry at BODC for all his assistance. The research described was funded by the Natural Environment Research Council, as part of Laboratory Research Project 2 of the Plymouth Marine Laboratory and of the North Sea Community Research Project. Partial financial support was given by the UK Ministry of Agriculture, Fisheries and Food, under contract GCA 10, and by the UK Department of the Environment as a contribution to its coordinated programme of research on the North Sea.

\section{LITERATURE CITED}

Davies, A. G., Madariaga, I. de, Bautista, B., Fernàndez, E., Harbour, D. S., Serret, P., Tranter, P. R. G. (1992). The ecology of a coastal Phaeocystis bloom in the north-west English Channel in 1990. J. mar. biol. Ass. U.K. 72:691-708

Gieskes, W. W. C., Kraay, G. W. (1980). Primary production and phytoplankton pigment measurements in the northern North Sea during FLEX '76. 'Meteor' Forsch.-Ergebn. A. 22: $105-112$

Gieskes, W. W. C., Kraay, G. W. (1984). Phytoplankton, its pigments, and primary production at a central North Sea station in May, July and September 1981. Neth. J. Sea Res. 18: $51-70$

Holligan, P. M., Aarup, T., Groom, S. B. (1989). The North Sea: satellite colour atlas. Cont. Shelf Res. 9: 667-765

Horwood, J. (1982). Algal production in the west-central North Sea. J. Plankton Res. 4: 103-124

Howarth, M. J., Dyer, K. R., Joint, I. R., Hydes, D. J., Purdie, D. A., Jones, J. E., Lowry, R. K., Moffat, T. J., Pomroy, A. J., Proctor, R. (1993). Seasonal cycles and their spatial variability. Phil. Trans. R. Soc. A 343: 383-403

ICES (1983). Flushing times of the North Sea. Co-operative research report 123, JCES, Copenhagen

Joint, I. R., Pomroy, A. J. (1983). Production of picoplankton and small nanoplankton in the Celtic Sea. Mar. Biol. 77 : $19-27$

This article was submitted to the editor
Joint, I., Pomroy, A., Savidge, G., Boyd, P. (1993). Phytoplankton productivity in the eastern North Atlantic; May to July 1989. Deep Sea Res. 40: 423-440

Lancelot, C., Mathot, S. (1987). Dynamics of a Phaeocystisdominated spring bloom in Belgian coastal waters. 1. Phytoplankton activities and related parameters. Mar. Ecol. Prog. Ser. 37: 239-248

NERC (1992). North Sea Project CD-ROM. British Oceanographic Data Base, Proudman Oceanographic Laboratory, Bidston Observatory, Birkenhead, L43 7RA, U.K.

Platt, T. (1986). Primary production of the ocean water column as a function of surface light intensity: algorithms for remote sensing. Deep Sea Res. 33: 149-163

Reid, P. C., Lancelot, C., Gieskes, W. W. C., Hagmeier, E. Weichart, G. (1990). Phytoplankton of the North Sea and its dynamics: a review. Neth. J. Sea Res. 26: 295-331

Riegman, R., Colijn, F. (1991). Evaluation of measurements and calculation of primary production in the Dogger Bank area (North Sea) in summer 1988. Mar. Ecol. Prog. Ser. 69: $125-132$

Strickland, J D. H., Parsons, T. R. (1972). A practical handbook of sea water analysis. Bull. Fish. Res. Bd Can 167: 185-205

Tijssen, S. B., Wetsteyn, F. J. (1984). Diurnal pattern, seasonal change and variability of oxygen in the water column of the Oyster Ground (North Sea) in spring-summer 1981. Neth. J. Sea Res. 18: 13-30

Veldhuis, M. J. W., Admiraal, W., Colijn, F. (1986). Chemical and physiological changes of phytoplankton during the spring bloom, dominated by Phaeocystis pouchetif (Haptophyceae): observations in Dutch coastal waters of the North Sea. Neth. J. Sea Res. 20:49-60

Verity, P. G., Villareal, T. A., Smayda, T. J. (1988). Ecological investigations of blooms of colonial Phaeocystis pouchetii I. Abundance, biochemical composition and metabolic rates. J. Plankton Res. 10: 219-248

Visser, M., Ruijter, W. P. M. de, Postma, L. (1991). The distribution of suspended matter in the Dutch coastal zone. Neth. J. Sea Res. 27: 127-143

Zevenboom, W., Rademaker, M., Colijn, F. (1991). Exceptional algal blooms in Dutch North Sea waters. Wat. Sci. Tech. 24: $251-260$

Manuscript first received: January 18, 1993

Revised version accepted: April 27, 1993 